\title{
Analysis of a Jup hypomorphic allele reveals a critical threshold for postnatal viability
}

\author{
David Swope ${ }^{1}$, Jifen Li $^{1}$, Eliane J. Muller ${ }^{2}$, and Glenn L. Radice ${ }^{1, \#}$ \\ ${ }^{1}$ Center for Translational Medicine, Department of Medicine, Thomas Jefferson University, \\ Philadelphia, PA, USA ${ }^{2}$ Molecular Dermatology, Institute Animal Pathology, Vetsuisse Faculty, \\ University of Bern, Bern, Switzerland
}

\begin{abstract}
Mutations in the human Jup gene cause arrhythmogenic right ventricular cardiomyopathy (ARVC) a heart muscle disease that often leads to sudden cardiac death. Inactivation of the murine Jup gene (also known as plakoglobin) results in embryonic lethality due to cardiac rupture. In an effort to generate a conditional knockout allele, a neomycin cassette was introduced into the murine plakoglobin $(P G)$ gene. This allele $\left(P G F^{N}\right)$ functions as a hypomorph when combined with a null allele $(P G \Delta)$. About half of the $\mathrm{PG} \mathrm{F}^{\mathrm{N}} / \Delta$ animals were smaller than their littermates and died before weaning age, whereas the remaining $\mathrm{PG} \mathrm{F}^{\mathrm{N}} / \Delta$ animals survived. Despite the reduced levels of PG in the heart, there were no signs of cardiomyopathy or cardiac dysfunction as determined by echocardiography. Importantly, the PG homolog, $\beta$-catenin (CTNNB1), was increased in the PG $\mathrm{F}^{\mathrm{N}} / \Delta$ hearts. In addition to its structural role as part of the $\mathrm{N}$-cadherin/catenin adhesion complex, $\beta$-catenin is a downstream effector of Wnt signaling. However, no change in $\beta$-catenin/TCF reporter activity was observed in $\mathrm{PG} \mathrm{F} / \Delta$ embryos suggesting that excess $\beta$-catenin was not likely causing increased transcription of $\mathrm{Wnt} / \beta$-catenin target genes. These data suggest novel function(s) for PG beyond the heart and define a critical threshold of PG expression that is necessary for postnatal survival.
\end{abstract}

\section{Keywords}

cell adhesion; intercalated disc; desmosome; adherens junction; cadherin; heart

\section{Introduction}

The structural integrity of the heart is dependent on mechanical junctions located at the endto-end connections between the myocytes called intercalated discs (ICD) (Kostetskii et al., 2005). The ICD consists of three main junctional complexes: adherens junctions, desmosomes and gap junctions. The adherens junction provides strong cell-cell adhesion, which is mediated by the cadherin/catenin complex via linkage to the actin cytoskeleton. The desmosome also provides structural support through interactions of desmosomal cadherins with the intermediate filament system. Recent data indicate mixing of adherens junctional and desmosomal components at the ICD resulting in a novel hybrid adhering junction or area composita found exclusively in the heart (Borrmann et al., 2006; Goossens et al., 2007). The gap junction provides intercellular communication via small molecules and ions that pass through a channel generated by a family of proteins called connexins.

\footnotetext{
\#Correspondence to: Dr. Glenn Radice, Center for Translational Medicine, Department of Medicine, Thomas Jefferson University, Rm 309 College Bldg., 1025 Walnut St., Philadelphia, PA 19107, Tel: (215) 503-5157, Fax: (215) 503-5731, glenn.radice@ jefferson.edu.
} 
Together these junctional complexes coordinate mechanical and electrical coupling between myocytes critical for efficient cardiac contractile function.

Plakoglobin is a unique ICD protein as it binds to the cytoplasmic domain of both classical cadherins and desmosomal cadherins thus mediating linkage to the actin and intermediate filaments, respectively. Mutations in the Jup gene were the first to be identified in arrhythmogenic right ventricular cardiomyopathy (ARVC) a heart muscle disease that causes sudden death in young people (McKoy et al., 2000). ARVC has distinct pathology consisting of progressive degeneration of cardiomyocytes and compensatory replacement with fibrofatty tissue (Basso et al., 2009; Delmar and McKenna, 2010; Sen-Chowdhry et al., 2010). This disease is associated with a significant risk of lethal arrhythmias. It is now well recognized that left ventricle involvement as well as biventricular disease is quite common in ARVC patients. As such a broader term of arrhythmogenic cardiomyopathy has been suggested for this disease (Basso et al., 2009). Almost half of ARVC patients have a mutation in at least one of the genes encoding the desmosomal proteins found at the ICD: desmocollin-2, desmoglein-2, plakoglobin, plakophilin-2, and desmoplakin. Interestingly, it has been reported that PG is reduced at the ICD in ARVC patients regardless of the desmosomal gene mutation causing the disease (Asimaki et al., 2009). Based on this finding it has been proposed that PG loss from the ICD may serve as a diagnostic marker of the disease. In addition to its structural role as part of the adhesion complex, plakoglobin like $\beta$ catenin, both vertebrate homologs of Drosophila armadillo, can modulate gene transcription together with the transcription cofactors T-cell factor/lymphoid enhancer factor (TCF/LEF) (Muller-Tidow et al., 2004; Williamson et al., 2006). In an animal model of ARVC, nuclear translocation of PG has been implicated in the fibro-fatty replacement of cardiomyocytes (Garcia-Gras et al., 2006). Hence, the role of PG in disease pathogenesis is likely more complicated than simply defective cell-cell adhesion between cardiomyocytes.

We recently reported that cardiac-specific deletion of murine $P G$ gene in the adult myocardium recapitulates many of the pathological features of ARVC (Li et al., 2011b). Here we describe a novel $P G$ hypomorphic allele that results in postnatal lethality. Surprisingly, significant reduction of PG at the ICD did not cause ARVC-like pathology in the $P G$ hypomorph mice. Interestingly, the PG homolog, $\beta$-catenin, was upregulated suggesting it may compensate, at least partially, for the reduction of PG in the mutant heart. The $P G$ hypomorph should prove useful for uncovering novel functions for PG in different cellular contexts.

\section{Results}

\section{Generation of a PG hypomorph model}

To overcome the requirement for PG during embryonic development, we generated a conditional PG (Jup) allele in mice ( $\mathrm{Li}$ et al., 2011b). The targeted floxed (F) allele referred to as $P G F^{N}$ contains a neomycin $(\mathrm{N})$ selection cassette inserted into intron 1 of the $P G$ gene (Fig. 1A). Deletion of the neomycin cassette using FLP recombinase results in a $P G$ floxed allele with wild-type levels of $\mathrm{PG}$ in the heart (data not shown). As we previously described (Li et al., 2011b), PG F/+ mice bred with protamine/Cre transgenic mice (O'Gorman et al., 1997 ) result in a germline null allele referred to as $P G \Delta$. As with $\mathrm{PG} \Delta /+$ mice, $P G \mathrm{~F}^{\mathrm{N}} / \mathrm{F}^{\mathrm{N}}$ mice were viable, fertile and show no obvious macroscopic phenotypic abnormality. The neomycin cassette contains cryptic splice sites that can often interfere with the expression of targeted genes (Meyers et al., 1998). To determine the consequence of leaving the neomycin cassette in the $P G$ gene, $\mathrm{PG} \mathrm{F} / \mathrm{F}^{\mathrm{N}}$ mice were bred with $\mathrm{PG} \Delta /+$ to generate $\mathrm{PG} \mathrm{F} / \Delta$ and $\mathrm{PG} \mathrm{F} /+$ mice. To determine if the presence of the neomycin cassette affected PG mRNA expression, qRT-PCR analysis was performed on $\mathrm{PG} \mathrm{F} / \Delta, \mathrm{PG} \Delta /+$ and $\mathrm{PG}+/+$ hearts. $\mathrm{PG}$ mRNA expression was significantly reduced $(\sim 35 \%$ of $\mathrm{WT}, \mathrm{n}=4, \mathrm{p}<0.05)$ in the $\mathrm{PG} \mathrm{F}^{\mathrm{N}} / \Delta$ 
hearts (Fig. 1B). Importantly, PG protein levels were reduced below $50 \%$ in the $\mathrm{PG} \mathrm{F}^{\mathrm{N}} / \Delta$ hearts $(\sim 40 \%$ of WT, $n=6, p<0.001)$ (Fig. 1C).

\section{Postnatal lethality of the PG $\mathrm{F}^{\mathrm{N}} / \Delta$ mice}

We observed that $\mathrm{PG} \mathrm{F}^{\mathrm{N}} / \Delta$ mice were underrepresented at weaning age $\left(\chi^{2}=6.76, \mathrm{p}<0.01\right.$, Table I). If we combined the genotyped $\mathrm{PG} \mathrm{F}^{\mathrm{N}} / \Delta$ and non-genotyped pups that died postnatally, then $\mathrm{PG} \mathrm{F} / \Delta$ mice were born at the expected Mendelian frequency (Table I). Moreover, no gross abnormalities were observed during embryonic stages E10.5 - E14.5 (data not shown), the developmental period when PG-null embryos die from heart defects (Bierkamp et al., 1996; Ruiz et al., 1996). Based on total pups born (Table I), about $40 \%$ of the $\mathrm{PG} \mathrm{F}^{\mathrm{N}} / \Delta$ pups did not survive to weaning age. The remaining $\mathrm{PG} \mathrm{F}^{\mathrm{N}} / \Delta$ mice survived to at least one year of age. PG functions as a critical component of the cell adhesion complex in the heart and importantly the PG gene is mutated in ARVC patients (Asimaki et al., 2007; McKoy et al., 2000). Therefore, the present study will focus on understanding the consequences of reducing PG levels in the heart. Although indistinguishable at birth, beginning around a week of age about half of the $\mathrm{PG} \mathrm{F}^{\mathrm{N}} / \Delta$ pups were noticeably smaller compared to their littermates (Fig. 2A). Presence of milk in the stomach indicated that the $\mathrm{PG} \mathrm{F}^{\mathrm{N}} / \Delta$ pups were able to nurse. To determine whether postnatal lethality correlated with differences in PG levels among the PG F $\mathrm{F}^{\mathrm{N}} / \Delta$ pups, qRT-PCR and Western analyses were performed at postnatal day (P) 5. No significant differences in PG mRNA or protein expression were observed among the $\mathrm{PG} \mathrm{F} / \Delta$ pups (data not shown). Thus, a difference in PG expression is not likely responsible for the incomplete penetrance of the postnatal lethality in the PG hypomorph animals. The $\mathrm{PG} \mathrm{F}^{\mathrm{N}} / \Delta$ hearts were smaller compared to their littermates (Fig. 2B), although there was no change in heart weight/body weight ratios (6.26 $\mathrm{mg} \pm 0.87\left[\mathrm{PG} \mathrm{F}^{\mathrm{N}} / \Delta\right]$ versus $\left.6.09 \mathrm{mg} \pm 0.57\left[\mathrm{PG} \mathrm{F}^{\mathrm{N}} /+\right], \mathrm{p}>0.05\right)$. Surprisingly, histological analysis did not detect any cellular or morphological abnormalities in the $\mathrm{PG} \mathrm{F}^{\mathrm{N}} / \Delta$ hearts at either P5 (data not shown) or P14 (Fig. 2C-H). Importantly, there were no signs of cardiac rupture as reported previously for the PG-null embryos (Bierkamp et al., 1996; Ruiz et al., 1996). Furthermore, myocytes loss and/or fibrosis were not observed in the $\mathrm{PG} \mathrm{F}^{\mathrm{N}} / \Delta$ hearts as reported for cardiac-specific PG knockout model (Li et al., 2011b) and ARVC patients (McKoy et al., 2000).

\section{Normal cardiac histology and function in $P G F^{N} / \Delta$ mice that survive the postnatal period}

The surviving PG F ${ }^{\mathrm{N}} / \Delta$ mice appeared healthy, however they did exhibit modest growth retardation compared to their littermates (Fig. 3). Immunofluorescence analysis revealed a significant reduction in $\mathrm{PG}$ at the ICD of $\mathrm{PG} \mathrm{F}^{\mathrm{N}} / \Delta$ hearts (Fig. 4E), consistent with the Western data (Fig. 1C). Both PG and $\beta$-catenin are capable of binding to the cytoplasmic domain of cadherins, therefore we examined $\beta$-catenin expression in PG hypomorph hearts. Interestingly, there was an increase in $\beta$-catenin at the ICD of the PG F ${ }^{\mathrm{N}} / \Delta$ hearts (Fig. $4 \mathrm{~F}$ ) suggesting $\beta$-catenin may compensate for reduced $\mathrm{PG}$ in the $\mathrm{N}$-cadherin/catenin adhesion complex. Importantly, $\mathrm{N}$-cadherin expression at the ICD was not altered in the $\mathrm{PG} \mathrm{F}^{\mathrm{N}} / \Delta$ hearts (Fig. 4G). In ARVC patients, the primary gap junction protein expressed in the myocardium, connexin43 (Cx43), is reduced at the ICD (Kaplan et al., 2004). However, $\mathrm{Cx} 43$ expression was not affected by the reduction in PG at the ICD (Fig. 4H).

PG is a unique junctional component as it serves as a cytoskeletal linker protein for both adherens junctions and desmosomes. We previously reported that PG is required for proper localization of desmosomal proteins at the ICD and for desmosome ultrastructure (Li et al., 2011b). To determine if desmosomal proteins were affected in the PG hypomorph, immunofluorescence analysis was performed on the $\mathrm{PG} \mathrm{F}^{\mathrm{N}} / \Delta$ hearts. There was no change in plakophilin-2 or desmoplakin expression at the ICD of the PG $\mathrm{F}^{\mathrm{N}} / \Delta$ hearts (Fig. 5) suggesting that the reduced levels of PG are sufficient to maintain desmosome organization. 
Similar to the postnatal mutant animals (Fig. 2), hearts of the surviving $\mathrm{PG} \mathrm{F}^{\mathrm{N}} / \Delta$ mice displayed normal histology with no signs of myocytes loss and/or fibrosis (Fig. 6A-F). To assess cardiac function, M-mode two-dimensional echocardiography of $\mathrm{PG} \mathrm{F}^{\mathrm{N}} / \Delta$ and control mice was performed at 12 months of age. Quantitative analysis of image data did not detect any change in left ventricular (LV) function as determined by ejection fraction and fraction shortening in the PG $\mathrm{F}^{\mathrm{N}} / \Delta$ mice (Fig. 6G). Moreover, $\mathrm{LV}$ end-systolic and diastolic internal dimension (LVID) measurements did not demonstrate increased chamber dimensions in $\mathrm{PG} \mathrm{F} \mathrm{F}^{\mathrm{N}} / \Delta$ mice (Fig. $6 \mathrm{H}$ ). $\mathrm{LV}$ anterior (LVAW) and posterior (LVPW) wall thickness was not changed in $\mathrm{PG} \mathrm{F} / \Delta$ mice further validating a lack of hypertrophic response (Fig. 6I). Thus, no signs of cardiomyopathy were observed in older $\mathrm{PG} \mathrm{F}^{\mathrm{N}} / \Delta$ mice.

\section{Increased $\beta$-catenin in $P G F^{N} / \Delta$ hearts}

The overall lack of a cardiac phenotype in the $\mathrm{PG} \mathrm{F}^{\mathrm{N}} / \Delta$ mice is surprising given the wellknown importance of PG in the heart. Western analysis indicated a two-fold increase in $\beta$ catenin protein in the $\mathrm{PG} \mathrm{F}^{\mathrm{N}} / \Delta$ hearts (Fig. 7A), consistent with the immunofluorescence data (Fig. 4F). Interestingly, $\beta$-catenin mRNA levels did not change in the $\mathrm{PG} \mathrm{F}^{\mathrm{N}} / \Delta$ hearts (Fig. 7B), indicating that posttranscriptional regulation was responsible for the upregulation of $\beta$-catenin. The GSK/axin/APC destruction complex tightly regulates the cytosolic levels of $\beta$-catenin, thus limiting the ability of $\beta$-catenin to interact with the transcription coactivators, TCF/LEF, and activate target genes. The activated $\beta$-catenin (ABC) antibody that recognizes dephosphorylated epitopes of $\beta$-catenin was used to monitor $\beta$-catenin stability (Maher et al., 2009). Interestingly, there was a significant increase in activated $\beta$-catenin consistent with the increased levels of the protein in the $\mathrm{PG} \mathrm{F}^{\mathrm{N}} / \Delta$ hearts (Fig. 7A).

In the unstressed adult heart, $\beta$-catenin is thought to function primarily as a structural protein as part of the $\mathrm{N}$-cadherin/catenin adhesion complex at the ICD. To investigate whether $\beta$ catenin signaling may be involved in the growth retardation and postnatal lethality of the PG $\mathrm{F}^{\mathrm{N}} / \Delta$ mice, we introduced the $\beta$-catenin/TCF/LEF reporter, BAT-gal transgene (Maretto et al., 2003) into the PG mutant background. In the course of our breeding we found that the BAT-gal transgene did not segregate randomly with respect to the $P G(J u p)$ allele indicating that these two genes are genetically linked. We observed several recombination events in the progeny from the following crosses: BAT-gal; PG $\Delta /+$ male X PG F $\mathrm{F}^{\mathrm{N}} / \mathrm{F}^{\mathrm{N}}$ female $(6 / 130)$ and PG F/F male X BAT-gal; PG F/+ female (5/71). We conclude from these genetic analyses that the BAT-gal transgene is located within several centimorgans $(11 / 201,5.47 \%$ recombination frequency) of the Jup gene on mouse chromosome 11.

$\mathrm{Wnt} / \beta$-catenin signaling is involved in many developmental processes, therefore we investigated whether reduced PG levels altered $\beta$-catenin/TCF/LEF reporter activity. Based on the lack of $\mathrm{Wnt} / \beta$-catenin signaling in the normal adult heart as well as that reported for the stabilized form of $\beta$-catenin (Hirschy et al., 2010), we decided to examine embryos where endogenous Wnt signaling is active. To examine $\mathrm{Wnt} / \beta$-catenin signaling in situ, PG $\mathrm{F}^{\mathrm{N}} / \Delta$; BAT-gal and control embryos were stained for $\beta$-galactosidase activity at midgestation. The overall pattern of BAT-gal activity appeared similar between the embryos (Fig. 7C). For quantitative analysis, $\beta$-galactosidase activity was measured in individual embryos carrying the BAT-gal transgene. No difference in BAT-gal reporter activity was observed in the PG $\mathrm{F}^{\mathrm{N}} / \Delta$ embryos (Fig. 7D). Taken together, these data suggest that changes in $\mathrm{Wnt} / \beta$-catenin signaling are not likely responsible for the postnatal lethality of the $\mathrm{PG} \mathrm{F}^{\mathrm{N}}$ / $\Delta$ mice.

\section{Discussion}

Mutations in the human Jup gene cause ARVC a heart muscle disease that often leads to sudden cardiac death in young people and athletes (Basso et al., 2009; Delmar and 
McKenna, 2010; Sen-Chowdhry et al., 2010). A recessive mutation identified in Jup results in a carboxy-terminal truncation of the PG protein (McKoy et al., 2000). This mutant form of PG was shown to decrease cell-cell adhesion in vitro supporting the hypothesis that defective mechanical coupling between cardiomyocytes is involved in the etiology of ARVC (Huang et al., 2008). Germline deletion of murine $P G$ gene results in embryonic lethality due to cardiac hemorrhage (Bierkamp et al., 1996; Ruiz et al., 1996). In the present study, we show that reduction of $\mathrm{PG}$ protein levels below $50 \%$ is compatible with embryonic development, however about half the $\mathrm{PG} \mathrm{F} / \Delta$ animals die prior to weaning. The remaining $\mathrm{PG} \mathrm{F}^{\mathrm{N}} / \Delta$ animals survive to at least 12 months of age and appear normal except for reduction in body mass. We and other investigators (Bierkamp et al., 1996; Kirchhof et al., 2006; Ruiz et al., 1996) have not observed postnatal lethality and/or growth retardation in PG heterozygous null animals indicating a further reduction in PG expression is necessary to elicit this phenotype.

Both cardiac-restricted PG loss-of-function (CKO) (Li et al., 2011b) and gain-of-function (Lombardi et al., 2011) studies have shown that altering PG expression can cause ARVClike pathology in mice. Despite the reduced levels of PG in the heart, there were no signs of cardiomyopathy or cardiac dysfunction as determined by echocardiography at 12 months of age. In our previous study of PG CKO mice (Li et al., 2011b), cardiac ejection fraction and fractional shortening were reduced in the mutant mice as early as 5 months after deleting the $P G$ gene in the heart. It was reported that $\mathrm{PG}$ heterozygous null mice develop right ventricular (RV) dysfunction with age in the absence of any pathological changes (Kirchhof et al., 2006). Interestingly, although the RV was affected as determined by echocardiography, no change in the left ventricle was observed in the PG heterozygous null mice. In future studies, it may prove informative to examine RV function in the PG hypomorph animals. An important pathological hallmark of ARVC is myocytes loss with fibrofatty replacement. The $\mathrm{PG} \mathrm{F} / \Delta$ hearts did not show any signs of cardiac degeneration, inflammation or fibrosis. The lack of cardiac pathology in the PG hypomorph model may be explained by the normal presence of desmosomal proteins at the ICD. In comparison, the complete loss of PG from the adult myocardium results in a dramatic reduction of desmosomal proteins at the ICD accompanied by abnormal desmosome ultrastructure (Li et al., 2011b). Hence, we conclude that the remaining PG protein at the ICD is sufficient to maintain adequate adhesion between the cardiomyocytes in the PG hypomorph hearts.

Like heart muscle, the epidermis is under constant mechanical stress. As such, mutations in cell adhesion molecules can result in skin abnormalities. Mutations have been identified in human JUP that result in palmoplantar keratoderma and woolly hair (Cabral et al., 2010; McKoy et al., 2000). Moreover, loss of PG from keratinocytes causes keratoderma in mice (Li et al., 2012). Additional studies are necessary to determine if structural alterations to the epidermis contribute to the postnatal lethality observed in the PG hypomorph animals.

PG and $\beta$-catenin are both capable of binding the cytoplasmic domain of $\mathrm{N}$-cadherin facilitating linkage to the actin cytoskeleton. Interestingly, $\beta$-catenin is upregulated in the $\mathrm{PG} \mathrm{F} / \Delta$ hearts suggesting it may compensate, at least partially, for PG in the $\mathrm{N}$-cadherin/ catenin adhesion complex. The cross-talk between these two closely related armadillo proteins occurs at the posttranscriptional level as there was no change in $\beta$-catenin mRNA expression in the $\mathrm{PG} \mathrm{F} / \Delta$ hearts. The cooperation of these two cadherin-binding proteins for maintaining the structural integrity of the heart was recently demonstrated by generating a cardiac-specific PG and $\beta$-catenin double knockout mouse (Swope et al., 2012). In contrast to single gene knockouts (Li et al., 2011b; Zhou et al., 2007), loss of both PG and $\beta$-catenin in the heart results in disassembly of the ICD and spontaneous lethal arrhythmias (Swope et al., 2012). In addition to its structural role as part of the cadherin/catenin complex, $\beta$-catenin is also a downstream effector of the Wnt signaling pathway. We speculated that stabilized $\beta$ - 
catenin in the $\mathrm{PG} \mathrm{F}^{\mathrm{N}} / \Delta$ mice may enhance $\mathrm{Wnt} / \beta$-catenin signaling, however we did not observe a change in BAT-gal reporter activity in mutant mice. The unchanged BAT-gal reporter activity in the PG hypomorph model is consistent with recent studies depleting PG in the heart (Li et al., 2011a) and skin (Li et al., 2012). In both these tissues, loss of PG had no effect on a similar transgene reporter (i.e. TOP-gal) despite stabilized $\beta$-catenin. Normal BAT-gal reporter activity in the PG hypomorph embryos may indicate that both armadillo proteins activate the TCF/LEF responsive elements thus the increase $\beta$-catenin in the mutant embryos may compensate for PG as a transcriptional co-activator. Further studies will be necessary to discern if the relative abundance of these armadillo proteins affects specific Wnt target genes.

Postnatal lethality occurs in about half the $\mathrm{PG} \mathrm{F}^{\mathrm{N}} / \Delta$ mice suggesting a single modifier gene may be responsible for the incomplete penetrance of this phenotype. A hallmark of the ARVC phenotype is incomplete penetrance and variable expressivity of the various desmosomal gene mutations. Of note, recent genetic studies suggest ARVC may be a multigenic disease as patients have been identified carrying mutations in more than one of the desmosomal genes (Bauce et al., 2010; Xu et al., 2010). In future studies, it will be interesting to map this modifier gene in the surviving $P G F^{N} / \Delta$ mice.

There is much interest in the research community to monitor endogenous Wnt signaling in many organs during development, regeneration and tumorigenesis. There are currently three lac Z reporter alleles commercially available that respond to endogenous Wnt/ $\beta$-catenin signaling (DasGupta and Fuchs, 1999; Lustig et al., 2002; Maretto et al., 2003). One such allele is a knockin of the bacterial lac Z gene into the Axin2 locus (Lustig et al., 2002). For our studies, the $A x i n 2^{l a c} Z$ allele is not convenient as it, like Jup, is located on mouse chromosome 11. The other two alleles are transgenic strains (TOP-gal and BAT-gal) containing TCF/LEF-binding motifs upstream of a minimal promoter driving lac $Z$ transgene expression (DasGupta and Fuchs, 1999; Maretto et al., 2003). The chromosomal insertion sites for these transgenic lines are not known; therefore we arbitrarily chose one of the strains for our experiments. During the course of our genetic cross, we discovered that the BAT-gal reporter is linked to the Jup gene on mouse chromosome 11. This genetic information may be helpful for investigators when deciding which $\mathrm{Wnt} / \beta$-catenin reporter strain to utilize in their experiments.

In this study, we define a critical threshold of PG expression that is necessary for postnatal growth and survival. Future studies will be necessary to discern the physiological reason for the postnatal lethality, as the $\mathrm{PG} \mathrm{F}^{\mathrm{N}} / \Delta$ mice exhibit no signs of cardiac pathology normally associated with $P G$ mutations. The $P G$ hypomorphic allele promises to stimulate a new appreciation of PG function beyond the heart.

\section{Methods}

\section{Generation of PG hypomorph mice}

The PG floxed allele containing the neomycin cassette $\left(\mathrm{F}^{\mathrm{N}}\right)$ and PG $\Delta /+$ were generated as previously described (Li et al., 2011b). The PG $\Delta /+$ mice were bred with $\mathrm{PG} \mathrm{F} / \mathrm{F}^{\mathrm{N}}$ and the progeny were genotyped by polymerase chain reaction (PCR) using specific primers as previously described (Li et al., 2011b). The BAT-gal transgenic mice (Maretto et al., 2003) were obtained from The Jackson Laboratory, Bar Harbor, ME. The mice were maintained on a mixed 129Sv-C57BL/6J genetic background. All animal experiments were performed in accordance with the guidelines of the IACUC of Thomas Jefferson University. 


\section{Histological analysis}

Hearts were isolated and fixed in $4 \%$ paraformaldehyde, dehydrated, and embedded in paraffin. Global heart architecture was determined from longitudinal 6- $\mu \mathrm{m}$ deparaffinized sections stained with hematoxylin and eosin (H\&E). Fibrosis was detected with Masson's trichrome stain (Sigma).

\section{Western blotting}

For Western blotting, hearts were homogenized in a modified radio-immunoprecipitation assay (RIPA) buffer (50 mM Tris- $\mathrm{HCl}$ [pH 7.5], $150 \mathrm{mM} \mathrm{NaCl}, 1 \mathrm{mM}$ EDTA [pH 8.0], $1 \%$ NP-40, $0.5 \%$ Na deoxycholate, $0.1 \%$ sodium dodecyl sulfate [SDS]) containing protease inhibitors and phosphatase inhibitor cocktails I and II (Roche Diagnostics) and centrifuged at $12,000 \times \mathrm{g}$ for $15 \mathrm{~min}$. Western blot analyses were performed with antibodies to $\mathrm{N}$ cadherin (3B9; Invitrogen), $\beta$-catenin (71-2700; Zymed), plakoglobin (15; BD Biosciences), Cx43 (C6219; Sigma), plakophilin-2 (Fitzgerald) and desmoplakin (Fitzgerald). For normalization of signals, blotting was also performed with an anti-GAPDH (6C5; RDI) monoclonal antibody, followed by incubation with an IRDye 680- or IRDye 800CWconjugated secondary antibody (LI-COR). Membranes were imaged with the Odyssey infrared imaging system (LI-COR), and quantitative densitometric analysis was performed with Odyssey version 1.2 infrared imaging software.

\section{Immunofluorescence analysis}

Paraffin-embedded heart sections $(6 \mu \mathrm{m})$ were mounted, dewaxed in xylene, rehydrated through an ethanol series, and then heated in $1 \times$ Antigen Unmasking Solution (Vector Laboratories) in a microwave oven $(350 \mathrm{~W})$ for 10 min to unmask the epitope. Following blocking with 5\% nonfat milk-PBS for 30 min, sections were incubated at $4{ }^{\circ} \mathrm{C}$ for $16 \mathrm{~h}$ with primary antibodies diluted in 5\% nonfat milk-PBS. The primary antibodies used are described above. After washing in PBS, sections were incubated with Alexa Fluor 488- or 555-conjugated goat anti-mouse or -rabbit antibody (Molecular Probes, Invitrogen) for $1 \mathrm{~h}$ at room temperature. After washing in PBS, sections were mounted using media (Vectashield) containing 4',6-diamidino-2-phenylindole (DAPI). Slides were imaged using a Zeiss LSM 510 META confocal microscope system.

\section{M-mode, two-dimensional echocardiography}

Transthoracic two-dimensional echocardiography on anesthetized (2\% inhaled isoflurane) mice was performed using the Vevo 770 high-resolution imaging system (Visual Sonics) equipped with a $30-\mathrm{MHz}$ probe. Left ventricular (LV) wall thickness and dimension were measured from M-mode images from the parasternal short-axis view at the plane bisecting the papillary muscles. Values were obtained by averaging three consecutive cardiac cycles, and ventricular fraction shortening (FS) and ejection fraction (EF) were calculated.

\section{RNA isolation, reverse transcription, and quantitative real-time PCR}

Total RNA was isolated from whole heart tissue using TRIZOL reagent according to the manufacturer's protocol (Invitrogen). cDNA was synthesized using the iScript cDNA synthesis kit (Bio-Rad), and PCR was performed with iQ SYBR Green Supermix (Bio-Rad) in the MyiQ single-color real-time PCR detection system (Bio-Rad). Gene expression was represented by the $\triangle \mathrm{CT}$ value normalized to the reference gene for glyceraldehyde 3phosphate dehydrogenase (GAPDH). The $\Delta \Delta \mathrm{CT}$ value of each target gene was then calculated by subtraction of the average $\Delta \mathrm{CT}$ from the control group. Finally, the $\mathrm{n}$-fold difference was calculated by using the formula $2-\Delta \Delta \mathrm{CT}$. Data from 4 heart samples from each group were collected and analyzed in triplicate. The primers used for real-time PCR were for plakoglobin (forward, $5^{\prime}$-CCTGTGGACTCTGCGCAAT-3'; reverse, $5^{\prime}$ - 
GACCAGGATCTTCAGCACACTCT-3'), $\beta$-catenin (forward, $5^{\prime}$ -

TGAATGGGAGCAAGGCTTTT- $3^{\prime}$; reverse, $5^{\prime}$-CATTGCATACTGCCCGTCAA- $3^{\prime}$ ), and GAPDH (forward, $5^{\prime}$-CCACTCTTCCACCTTCGATG- $3^{\prime}$; reverse, $5^{\prime}$ TCCACCACCCTGTTGCTGTA-3').

\section{$\beta$-galactosidase detection in embryos}

Mouse embryos were isolated from pregnant mothers at E10.5. Wholemount X-gal staining of embryos was performed as previously described (Luo et al., 2005). A lacZ gene activity detection kit (Sigma, GAL-A) was used to measure $\beta$-galactosidase activity in individual embryos. The assay was performed in accordance with manufacturer's instructions. Briefly, embryos were lysed, incubated with o-nitrophenyl $\beta$-D-galactopyranoside (ONPG) for 30 minutes at $37^{\circ} \mathrm{C}$ and quenched with a stop solution. $\beta$-galactosidase activity was then detected by reading the OD at $420 \mathrm{~nm}$ using a spectrometer.

\section{Statistics}

Data are expressed as the mean \pm the standard error of the mean (SEM). Unless otherwise noted, comparisons between groups were performed with a two-tailed Student $t$ test. A P value of $<0.05$ was considered statistically significant.

\section{Acknowledgments}

We thank Leeanne Griffith for technical assistance. This work was supported by National Institutes of Health (HL081569 to GR, T32AR052273 to DS), American Heart Association Predoctoral Fellowship (PRE7360047 to DS) and Scientist Development Grant (N2080068 to JL).

Funded in part by NIH grant HL081569

\section{References}

Asimaki A, Syrris P, Wichter T, Matthias P, Saffitz JE, McKenna WJ. A novel dominant mutation in plakoglobin causes arrhythmogenic right ventricular cardiomyopathy. Am J Hum Genet. 2007; 81:964-973. [PubMed: 17924338]

Asimaki A, Tandri H, Huang H, Halushka MK, Gautam S, Basso C, Thiene G, Tsatsopoulou A, Protonotarios N, McKenna WJ, Calkins H, Saffitz JE. A new diagnostic test for arrhythmogenic right ventricular cardiomyopathy. N Engl J Med. 2009; 360:1075-1084. [PubMed: 19279339]

Basso C, Corrado D, Marcus FI, Nava A, Thiene G. Arrhythmogenic right ventricular cardiomyopathy. Lancet. 2009; 373:1289-1300. [PubMed: 19362677]

Bauce B, Nava A, Beffagna G, Basso C, Lorenzon A, Smaniotto G, De Bortoli M, Rigato I, Mazzotti E, Steriotis A, Marra MP, Towbin JA, Thiene G, Danieli GA, Rampazzo A. Multiple mutations in desmosomal proteins encoding genes in arrhythmogenic right ventricular cardiomyopathy/ dysplasia. Heart Rhythm. 2010; 7:22-29. [PubMed: 20129281]

Bierkamp C, McLaughlin KJ, Schwarz H, Huber O, Kemler R. Embryonic heart and skin defects in mice lacking plakoglobin. Dev Biol. 1996; 180:780-785. [PubMed: 8954745]

Borrmann CM, Grund C, Kuhn C, Hofmann I, Pieperhoff S, Franke WW. The area composita of adhering junctions connecting heart muscle cells of vertebrates. II. Colocalizations of desmosomal and fascia adhaerens molecules in the intercalated disk. Eur J Cell Biol. 2006; 85:469-485. [PubMed: 16600422]

Cabral RM, Liu L, Hogan C, Dopping-Hepenstal PJ, Winik BC, Asial RA, Dobson R, Mein CA, Baselaga PA, Mellerio JE, Nanda A, Boente Mdel C, Kelsell DP, McGrath JA, South AP. Homozygous mutations in the 5' region of the JUP gene result in cutaneous disease but normal heart development in children. J Invest Dermatol. 2010; 130:1543-1550. [PubMed: 20130592]

DasGupta R, Fuchs E. Multiple roles for activated LEF/TCF transcription complexes during hair follicle development and differentiation. Development. 1999; 126:4557-4568. [PubMed: 10498690] 
Delmar M, McKenna WJ. The cardiac desmosome and arrhythmogenic cardiomyopathies: from gene to disease. Circ Res. 2010; 107:700-714. [PubMed: 20847325]

Garcia-Gras E, Lombardi R, Giocondo MJ, Willerson JT, Schneider MD, Khoury DS, Marian AJ. Suppression of canonical Wnt/beta-catenin signaling by nuclear plakoglobin recapitulates phenotype of arrhythmogenic right ventricular cardiomyopathy. J Clin Invest. 2006; 116:20122021. [PubMed: 16823493]

Goossens S, Janssens B, Bonne S, De Rycke R, Braet F, van Hengel J, van Roy F. A unique and specific interaction between alphaT-catenin and plakophilin-2 in the area composita, the mixedtype junctional structure of cardiac intercalated discs. J Cell Sci. 2007; 120:2126-2136. [PubMed: 17535849]

Hirschy A, Croquelois A, Perriard E, Schoenauer R, Agarkova I, Hoerstrup SP, Taketo MM, Pedrazzini T, Perriard JC, Ehler E. Stabilised beta-catenin in postnatal ventricular myocardium leads to dilated cardiomyopathy and premature death. Basic Res Cardiol. 2010; 105:597-608. [PubMed: 20376467]

Huang H, Asimaki A, Lo D, McKenna W, Saffitz J. Disparate effects of different mutations in plakoglobin on cell mechanical behavior. Cell Motil Cytoskeleton. 2008; 65:964-978. [PubMed: 18937352]

Kaplan SR, Gard JJ, Protonotarios N, Tsatsopoulou A, Spiliopoulou C, Anastasakis A, Squarcioni CP, McKenna WJ, Thiene G, Basso C, Brousse N, Fontaine G, Saffitz JE. Remodeling of myocyte gap junctions in arrhythmogenic right ventricular cardiomyopathy due to a deletion in plakoglobin (Naxos disease). Heart Rhythm. 2004; 1:3-11. [PubMed: 15851108]

Kirchhof P, Fabritz L, Zwiener M, Witt H, Schafers M, Zellerhoff S, Paul M, Athai T, Hiller KH, Baba HA, Breithardt G, Ruiz P, Wichter T, Levkau B. Age- and training-dependent development of arrhythmogenic right ventricular cardiomyopathy in heterozygous plakoglobin-deficient mice. Circulation. 2006; 114:1799-1806. [PubMed: 17030684]

Kostetskii I, Li J, Xiong Y, Zhou R, Ferrari VA, Patel VV, Molkentin JD, Radice GL. Induced deletion of the $\mathrm{N}$-cadherin gene in the heart leads to dissolution of the intercalated disc structure. Circ Res. 2005; 96:346-354. [PubMed: 15662031]

Li D, Liu Y, Maruyama M, Zhu W, Chen H, Zhang W, Reuter S, Lin SF, Haneline LS, Field LJ, Chen PS, Shou W. Restrictive loss of plakoglobin in cardiomyocytes leads to arrhythmogenic cardiomyopathy. Hum Mol Genet. 2011a; 20:4582-4596. [PubMed: 21880664]

Li D, Zhang W, Liu Y, Haneline LS, Shou W. Lack of plakoglobin in epidermis leads to keratoderma. J Biol Chem. 2012; 287:10435-10443. [PubMed: 22315228]

Li J, Swope D, Raess N, Cheng L, Muller EJ, Radice GL. Cardiac tissue-restricted deletion of plakoglobin results in progressive cardiomyopathy and activation of \{beta $\}$-catenin signaling. Mol Cell Biol. 2011b; 31:1134-1144. [PubMed: 21245375]

Lombardi R, da Graca Cabreira-Hansen M, Bell A, Fromm RR, Willerson JT, Marian AJ. Nuclear plakoglobin is essential for differentiation of cardiac progenitor cells to adipocytes in arrhythmogenic right ventricular cardiomyopathy. Circ Res. 2011; 109:1342-1353. [PubMed: 22021931]

Luo Y, Kostetskii I, Radice GL. N-cadherin is not essential for limb mesenchymal chondrogenesis. Dev Dyn. 2005; 232:336-344. [PubMed: 15614770]

Lustig B, Jerchow B, Sachs M, Weiler S, Pietsch T, Karsten U, van de Wetering M, Clevers H, Schlag PM, Birchmeier W, Behrens J. Negative feedback loop of Wnt signaling through upregulation of conductin/axin2 in colorectal and liver tumors. Mol Cell Biol. 2002; 22:1184-1193. [PubMed: 11809809]

Maher MT, Flozak AS, Stocker AM, Chenn A, Gottardi CJ. Activity of the beta-catenin phosphodestruction complex at cell-cell contacts is enhanced by cadherin-based adhesion. J Cell Biol. 2009; 186:219-228. [PubMed: 19620634]

Maretto S, Cordenonsi M, Dupont S, Braghetta P, Broccoli V, Hassan AB, Volpin D, Bressan GM, Piccolo S. Mapping Wnt/beta-catenin signaling during mouse development and in colorectal tumors. Proc Natl Acad Sci U S A. 2003; 100:3299-3304. [PubMed: 12626757]

McKoy G, Protonotarios N, Crosby A, Tsatsopoulou A, Anastasakis A, Coonar A, Norman M, Baboonian C, Jeffery S, McKenna WJ. Identification of a deletion in plakoglobin in 
arrhythmogenic right ventricular cardiomyopathy with palmoplantar keratoderma and woolly hair (Naxos disease). Lancet. 2000; 355:2119-2124. [PubMed: 10902626]

Meyers EN, Lewandoski M, Martin GR. An Fgf8 mutant allelic series generated by Cre- and Flpmediated recombination. Nat Genet. 1998; 18:136-141. [PubMed: 9462741]

Muller-Tidow C, Steffen B, Cauvet T, Tickenbrock L, Ji P, Diederichs S, Sargin B, Kohler G, Stelljes M, Puccetti E, Ruthardt M, deVos S, Hiebert SW, Koeffler HP, Berdel WE, Serve H. Translocation products in acute myeloid leukemia activate the Wnt signaling pathway in hematopoietic cells. Mol Cell Biol. 2004; 24:2890-2904. [PubMed: 15024077]

O'Gorman S, Dagenais NA, Qian M, Marchuk Y. Protamine-Cre recombinase transgenes efficiently recombine target sequences in the male germ line of mice, but not in embryonic stem cells. Proc Natl Acad Sci U S A. 1997; 94:14602-14607. [PubMed: 9405659]

Ruiz P, Brinkmann V, Ledermann B, Behrend M, Grund C, Thalhammer C, Vogel F, Birchmeier C, Gunthert U, Franke WW, Birchmeier W. Targeted mutation of plakoglobin in mice reveals essential functions of desmosomes in the embryonic heart. J Cell Biol. 1996; 135:215-225. [PubMed: 8858175]

Sen-Chowdhry S, Morgan RD, Chambers JC, McKenna WJ. Arrhythmogenic cardiomyopathy: etiology, diagnosis, and treatment. Annu Rev Med. 2010; 61:233-253. [PubMed: 20059337]

Swope D, Cheng L, Gao E, Li J, Radice GL. Loss of cadherin-binding proteins beta-catenin and plakoglobin in the heart leads to gap junction remodeling and arrhythmogenesis. Mol Cell Biol. 2012; 32:1056-1067. [PubMed: 22252313]

Williamson L, Raess NA, Caldelari R, Zakher A, de Bruin A, Posthaus H, Bolli R, Hunziker T, Suter MM, Muller EJ. Pemphigus vulgaris identifies plakoglobin as key suppressor of c-Myc in the skin. EMBO J. 2006; 25:3298-3309. [PubMed: 16871158]

Xu T, Yang Z, Vatta M, Rampazzo A, Beffagna G, Pilichou K, Scherer SE, Saffitz J, Kravitz J, Zareba W, Danieli GA, Lorenzon A, Nava A, Bauce B, Thiene G, Basso C, Calkins H, Gear K, Marcus F, Towbin JA. Compound and digenic heterozygosity contributes to arrhythmogenic right ventricular cardiomyopathy. J Am Coll Cardiol. 2010; 55:587-597. [PubMed: 20152563]

Zhou J, Qu J, Yi XP, Graber K, Huber L, Wang X, Gerdes AM, Li F. Upregulation of gamma-catenin compensates for the loss of beta-catenin in adult cardiomyocytes. Am J Physiol Heart Circ Physiol. 2007; 292:H270-H276. [PubMed: 16936006] 
A

Wild-type allele

Targeting vector

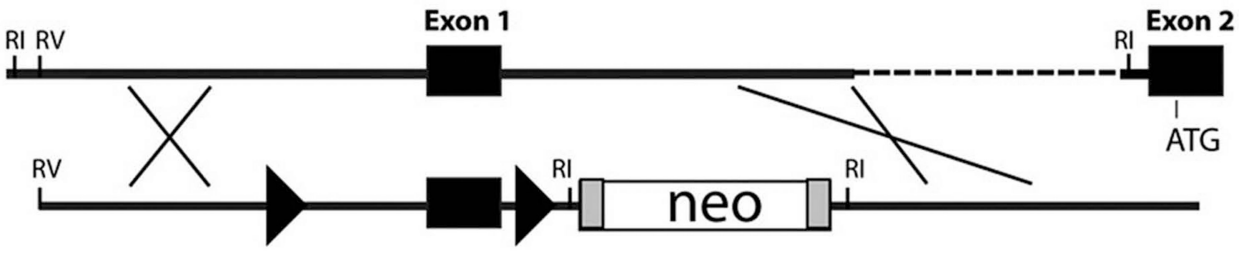

$\mathrm{F}^{\mathrm{N}}$ Targeted allele

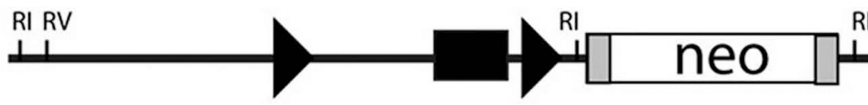

$\triangle$ Deleted allele
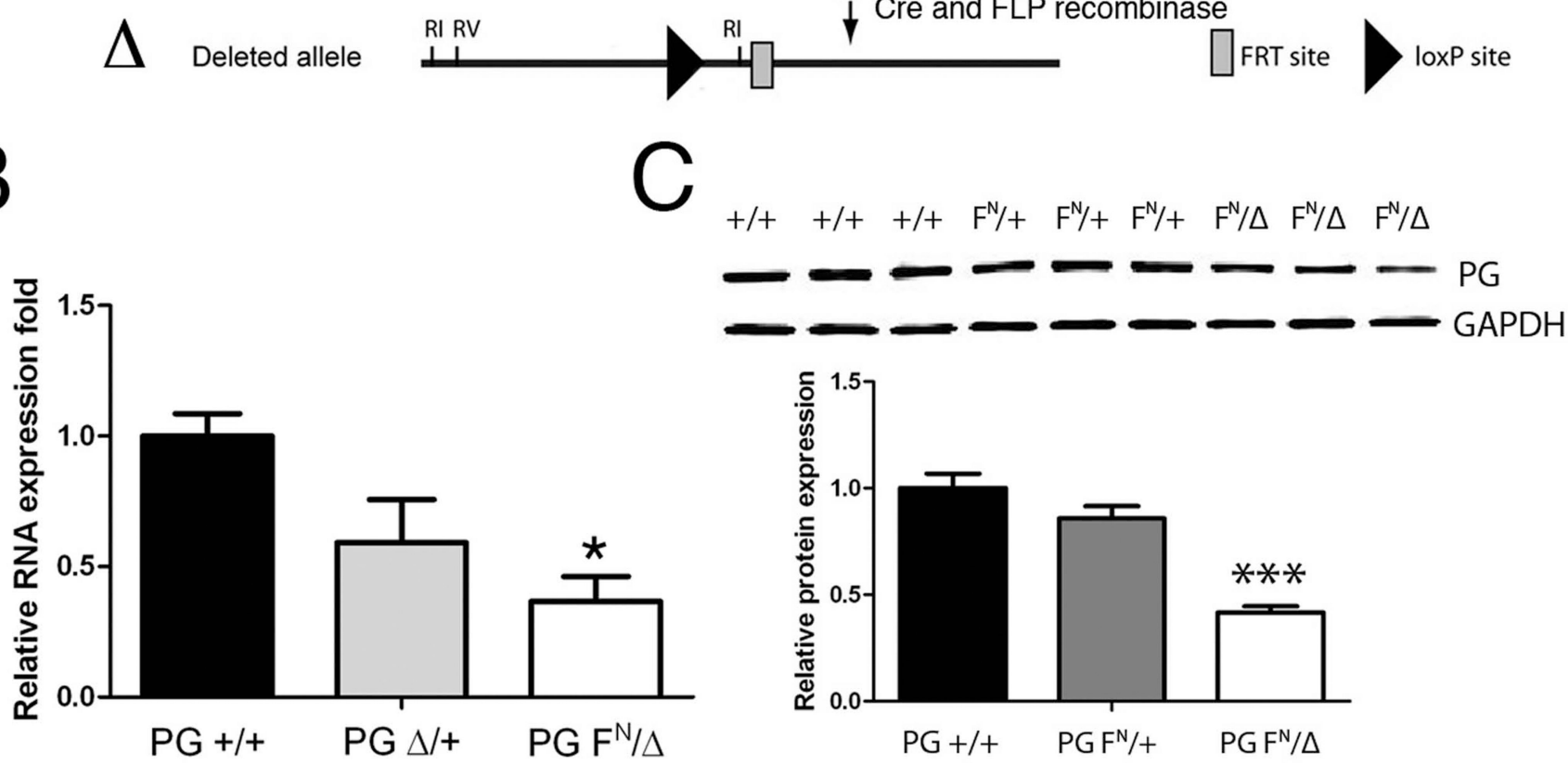

$\mathrm{B}$

Figure 1. Generation of PG hypomorph mouse model

(A) Schematic representation of the expected gene replacement at the PG locus. loxP sites are represented by triangles. The rectangles represent FRT sites. The combination of PG floxed allele $\left(\mathrm{F}^{\mathrm{N}}\right)$ containing a neomycin cassette (neo) with the germline null allele $(\Delta)$ resulted in a PG hypomorph (PG F $\mathrm{F}^{\mathrm{N}} / \Delta$ ). (B) Quantification of PG mRNA expression in PG $+/+$, PG $\Delta /+$, and PG $\mathrm{F}^{\mathrm{N}} / \Delta$ hearts ( $\mathrm{n}=4$ for each genotype) at 3 months of age. (C)

Representative Western blot of heart lysates from 1 month old $\mathrm{PG}+/+, \mathrm{PG} \mathrm{F}^{\mathrm{N}} /+$ and $\mathrm{PG} \mathrm{F}^{\mathrm{N}} /$ $\Delta$ mice ( $\mathrm{n}=6$ for each genotype) were immunoblotted for PG and GAPDH. *, $\mathrm{p}<0.05$; ***, $\mathrm{p}<0.001$. 

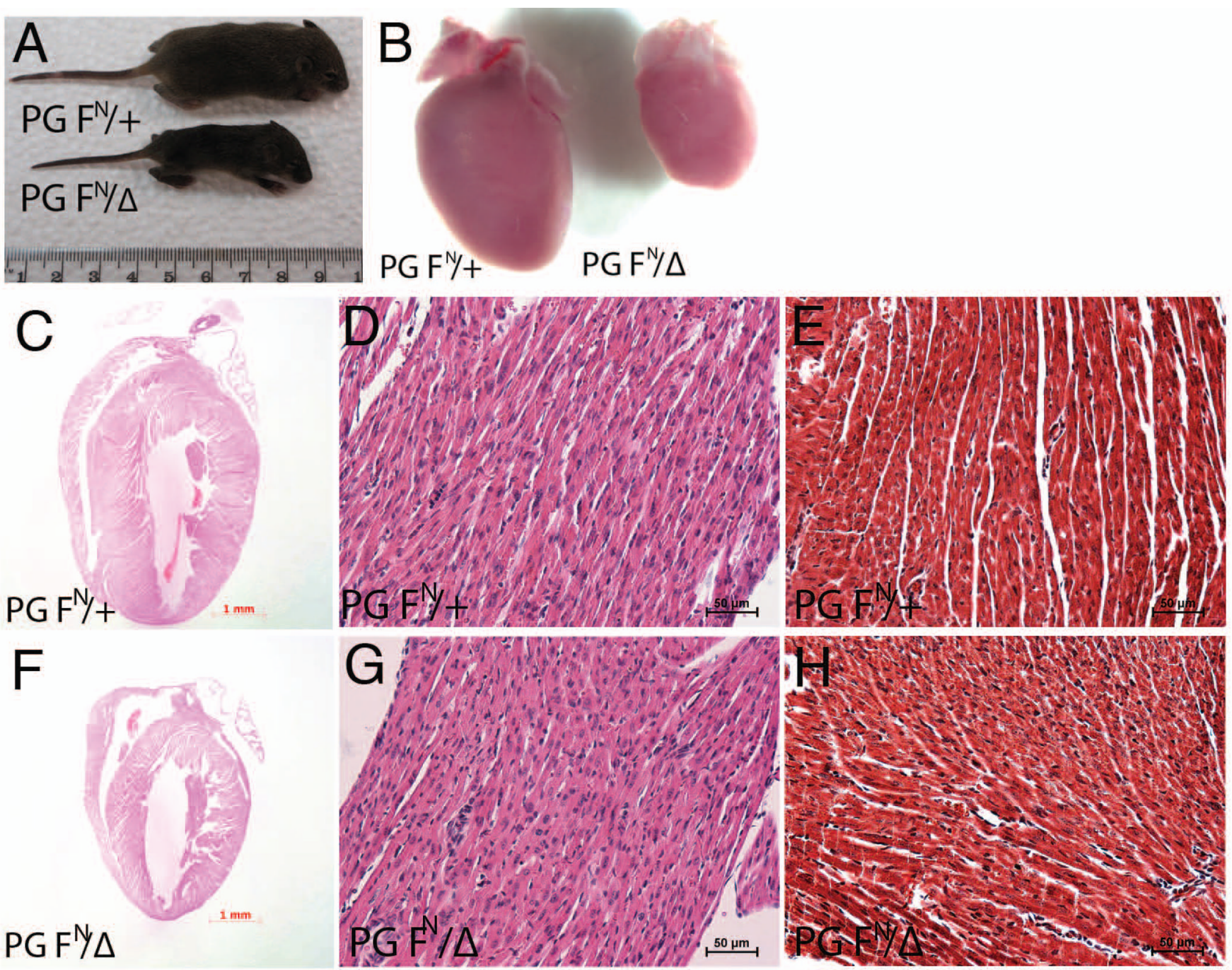

Figure 2. Histological analysis of PG hypomorph heart

(A) Representative image of PG hypomorph mouse $\left(\mathrm{PG} \mathrm{F}^{\mathrm{N}} / \Delta\right)$ at postnatal day 10 compared to control littermate ( $\mathrm{PG} \mathrm{F}^{\mathrm{N}} /+$ ). (B) Representative image of $\mathrm{PG}$ hypomorph heart $\left(\mathrm{PG} \mathrm{F}^{\mathrm{N}}\right.$ / $\Delta$ ) at postnatal day 10 compared to control littermates ( $\mathrm{PG} \mathrm{F}^{\mathrm{N}} /+$ ). (C-H) Heart sections from $P G F^{\mathrm{N}} /+$ and $P G \mathrm{~F}^{\mathrm{N}} / \Delta$ mice 14 days old were stained with $\mathrm{H} \& \mathrm{E}(\mathrm{C}, \mathrm{D}, \mathrm{F}, \mathrm{G})$ or Masson's trichrome $(\mathrm{E}, \mathrm{H})$. 


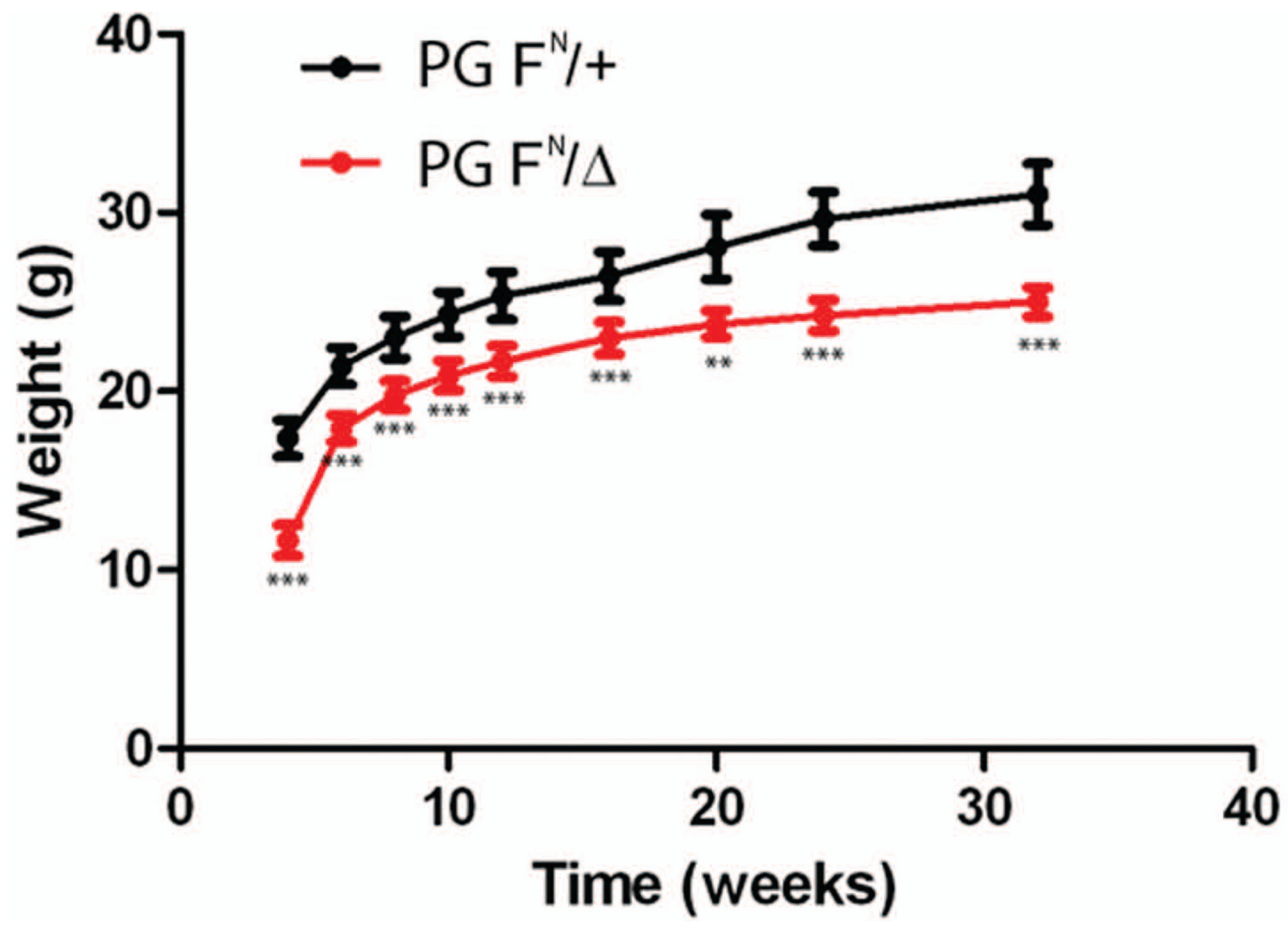

Figure 3. Growth retardation in surviving PG hypomorph mice

Body weight measurements of $\mathrm{PG}$ hypomorph $\left(\mathrm{PG} \mathrm{F}^{\mathrm{N}} / \Delta\right)$ and control littermates $\left(\mathrm{PG} \mathrm{F}^{\mathrm{N}} /+\right.$ ) taken between $4-32$ weeks of age. **, p $<0.01 ; * * *, p<0.001$. 


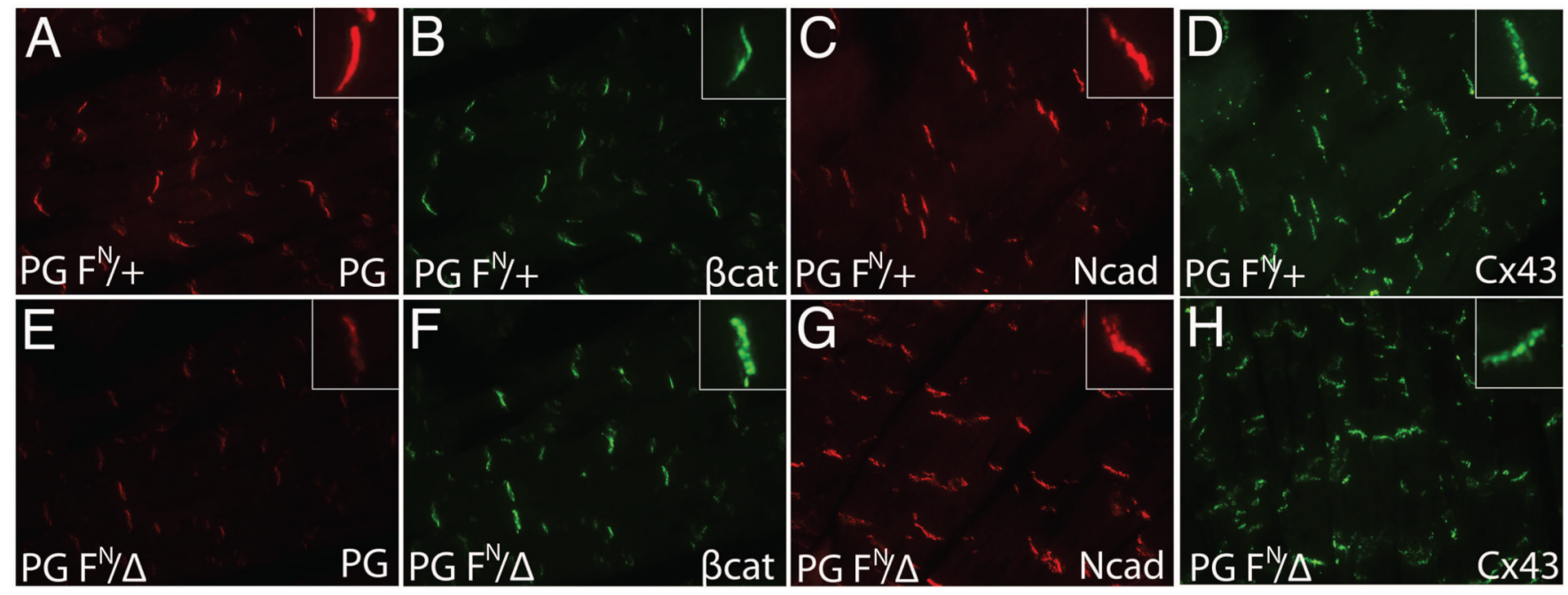

Figure 4. ICD expression of junctional proteins in PG hypomorph heart

Heart sections from $\mathrm{PG} \mathrm{F} /+(\mathrm{A}, \mathrm{B}, \mathrm{C}, \mathrm{D})$ and $\mathrm{PG} \mathrm{F} \mathrm{F}^{\mathrm{N}} / \Delta(\mathrm{E}, \mathrm{F}, \mathrm{G}, \mathrm{H})$ mice at 5 months were immunostained for plakoglobin $(\mathrm{PG})(\mathrm{A}, \mathrm{E}), \beta$-catenin $(\beta$-cat) $(\mathrm{B}, \mathrm{F}), \mathrm{N}$-cadherin $(\mathrm{Ncad})$ $(C, G)$ and $C x 43(D, H)$. Insets show higher magnification of ICD staining. Note the decreased expression of PG and modest upregulation of $\beta$-cat at the ICD of PG hypomorph hearts compared with controls. No significant change was seen in either N-cadherin or Cx43 expression at the ICD. 


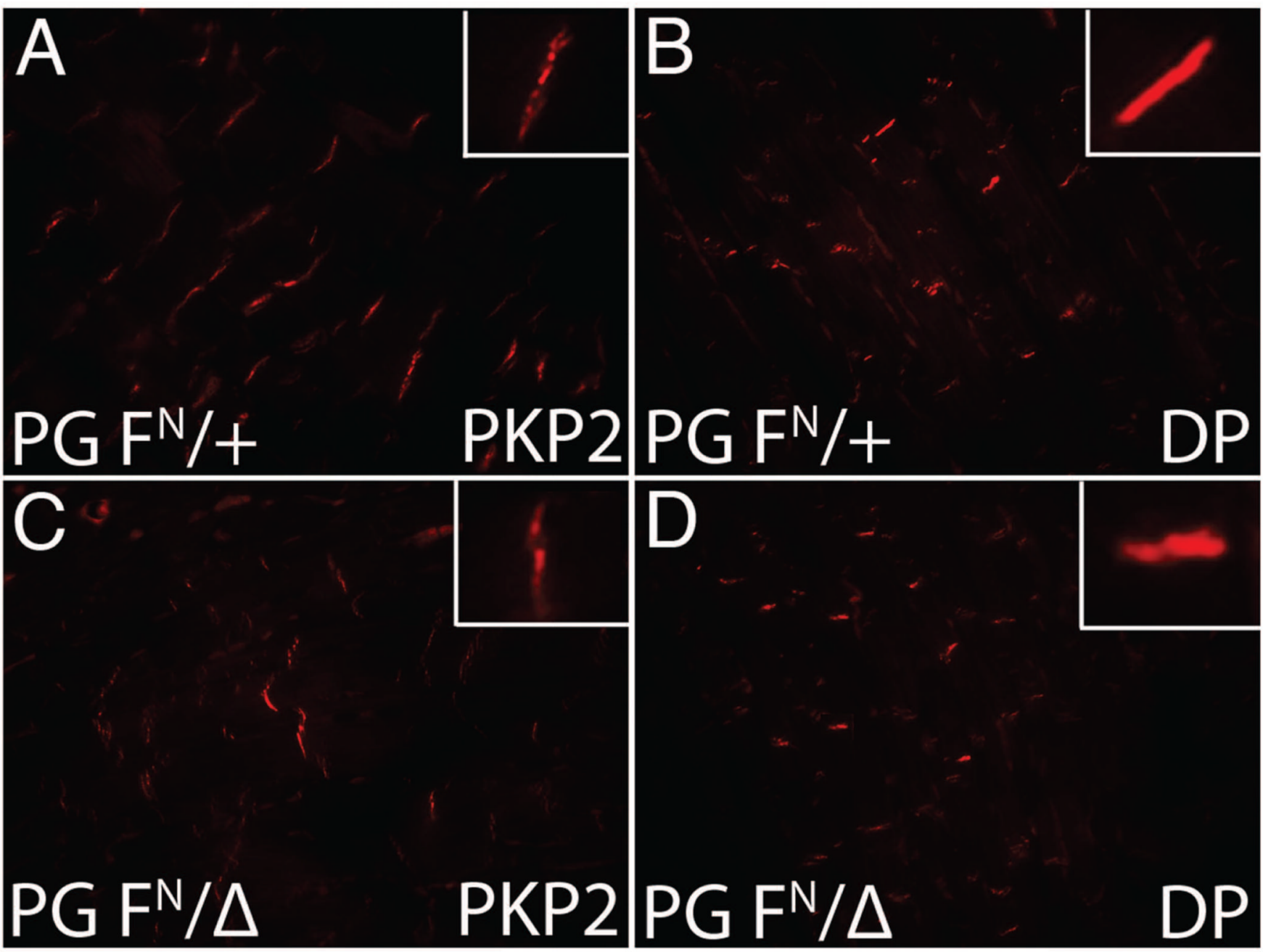

Figure 5. ICD expression of desmosomal proteins in PG hypomorph heart Heart sections from $\mathrm{PG} \mathrm{F} /+(\mathrm{A}, \mathrm{B})$ and $\mathrm{PG} \mathrm{F} / \Delta(\mathrm{C}, \mathrm{D})$ mice at 5 months were immunostained for plakophilin-2 (PKP2) (A,C) and desmoplakin (DP) (B,D). Insets show higher magnification of ICD staining. No significant change was seen in either PKP2 or DP expression at the ICD. 

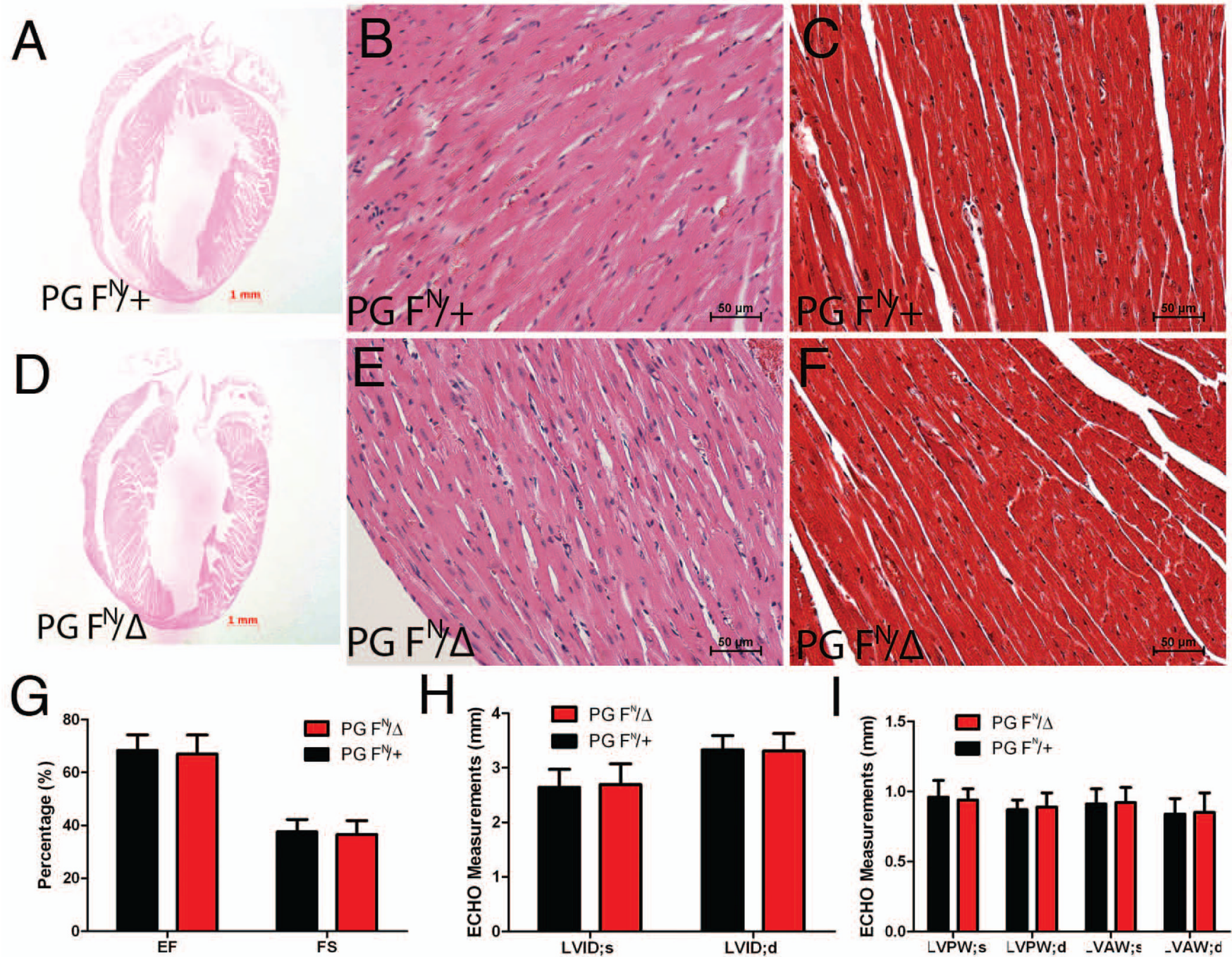

Figure 6. Cardiac histology and functional analysis in PG hypomorph mice Heart sections from $\mathrm{PG} \mathrm{F} /+$ and $\mathrm{PG} \mathrm{F} / \Delta$ mice at 5 months were $\mathrm{H} \& \mathrm{E}(\mathrm{A}, \mathrm{B}, \mathrm{D}, \mathrm{E})$ or Masson's trichrome (C,F) stained. (G-I) M-mode two-dimensional echocardiography measurements of ejection fraction (EF) and fractional shortening (FS), left ventricular endsystolic and -diastolic internal dimension (LVID), and left ventricular posterior and anterior wall thickness during systole and diastole (LVPW, LVAW; respectively) for PG hypomorph $(n=9)$ and control $(n=6)$ mice at 12 months of age. No signs of cardiac pathology, fibrosis, hypertrophy or reduced cardiac function were seen in PG hypomorph mice. 

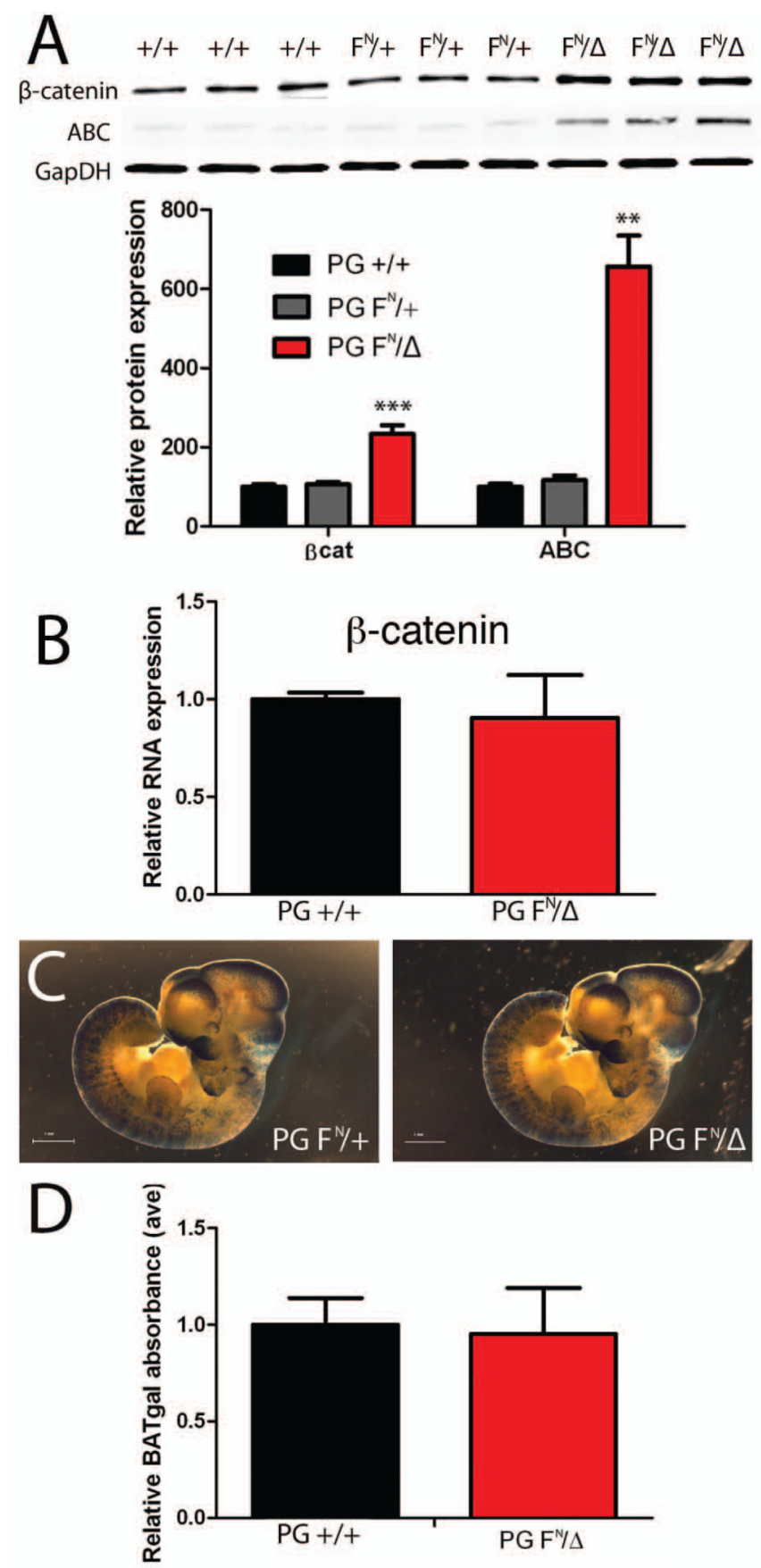

Figure 7. $\beta$-catenin expression in PG hypomorph mice

(A) Representative Western blot of heart lysates from 1 month old $\mathrm{PG}+/+, \mathrm{PG} \mathrm{F}^{\mathrm{N}} /+$ and $\mathrm{PG}$ $\mathrm{F}^{\mathrm{N}} / \Delta$ mice $(\mathrm{n}=6$ for each genotype) probed for $\beta$-catenin $(\beta$-cat), activated $\beta$-catenin $(\mathrm{ABC})$ and GAPDH. Note the significant increase in total $\beta$-catenin and ABC protein levels in PG hypomorph hearts. (B) Quantification of $\beta$-catenin mRNA expression in $\mathrm{PG}+/+(\mathrm{n}=4)$ and $P G F^{N} / \Delta(n=4)$ hearts at 3 months of age. (C) Representative images of $P G F^{N} /+$; BAT-gal and PG $\mathrm{F}^{\mathrm{N}} / \Delta$; BAT-gal embryos at E10.5 stained with X-gal. (D) Quantification of $\beta$ galactosidase activity in PG +/+; BAT-gal $(n=30)$ and $\mathrm{PG} \mathrm{F}^{\mathrm{N}} / \Delta$; BAT-gal $(\mathrm{n}=23)$ embryos at E10.5. **, $\mathrm{p}<0.01 . * * *, \mathrm{p}<0.001$. 


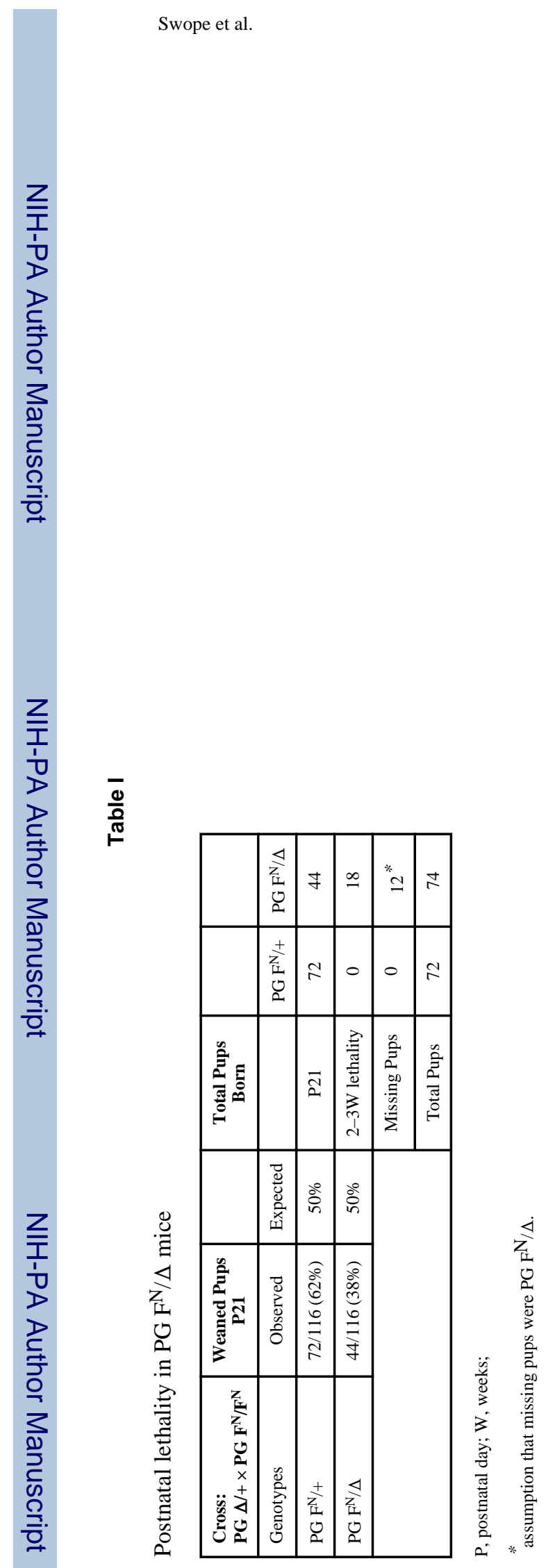

Genesis. Author manuscript; available in PMC 2013 October 01. 